\title{
The Research on Financing of New-Model Culture Industry
}

\author{
Peiyuan Li \& Yaping Wei \\ College of industrial and commercial administration \\ Tianjin Polytechnic University \\ Tianjin 300387, China
}

\begin{abstract}
New-model Culture Industry is a newly-developing industry even in the whole world, and is also a "sunrise" industry. In this paper, a full-scale view over the direct financing of New-model Culture Industry in China will be taken. The Paper discussed New-model Culture Industry of china in many angles, like the definition of New-model Culture Industry, the direct financing of New-model culture Industry; these problems are mostly have no universal answers. Based on the generalization and analysis of many researchers, the paper advanced its own opinion on these problems. At last, through the empirically research, we establish a Direct Finance Model of New-model Culture Industry. Hopefully, this Direct Finance Model will help the development of our country's New-model Culture Industry.
\end{abstract}

Keywords: New-model culture industry, Direct financing, Direct finance model of new-model culture industry

\section{Introduction}

At present, regardless of the observation which comes from the practice or from the theory, we discovered clearly that sustainable development of the cultural and economic integration development is the tendency which the modern society develops. This trend of development enabled the New-model Culture Industry to become the "sunrise" industry which recognized in the world. Early stats shows that the American New-model Culture Industry's output value occupies approximately 1/5 GDP; Japanese economy which had once created the world miracle, its cultural industry is also core industry.

\section{Characteristics of the New-model culture industry}

In china, the cultural industry's first development is based by culture structural reforms. Because the culture structural reforms still lagged, the market mechanism has not completed completely, Such as media industry admittance barrier existences and so on. Lots of the cultural industry resources IS restricted and only used in the government's departments. Therefore, the development result of the traditional culture industrial cannot meet the social need. However, take informationization, technicalization as characteristic the New-model Culture Industry had a broad develop market. In china, a large number of surplus capital crosses the system restriction of the traditional culture industry, invests to the New-model Culture Industry domain. The New-model Culture Industry New cultural industry investment cost's increase causes the traditional culture industry to decline gradually. Complies with the situation, we must develop the new cultural industry emphatically vigorously.

The New-model Culture Industry is based by the high and new technology and the private capital, compares traditional culture industry, the superiority is obviously: Firstly, the New-model Culture Industry's potential is huge, and it keeps pace with the times. The New-model Culture Industry is the driving force for rapid development of electronic information science and technology. The modernization is the high tech socialization, it founds inevitably the new economical time. And the new economical reflection is the New-model Culture Industry. Secondly, the multiplication finances. Without the institutional barrier, the New-model Culture Industry can attract private surplus capital. And it also can adapt the market and the social need. Third, the market is broad and consumer is good.

New cultural industries and new consumer grow up groups at the same time. The multiplication finances as a new social production and consumption's new combination, it has a great market prospect For example emerging media, because the originality, interactive, the experience, convenient, the information content big and so on merits have won consumer's favor rapidly.

\section{Direct financing model of the new-model culture industry}

\subsection{Present situation of our country's New-model Culture Industry}

In recent years, threw the financing gradual growth along with the cultural domain, our country's the New-model Culture Industry obtained a quick development. But compares with the overseas developed country and the area, our country new culture industry is just at the start stage In the New-model Culture Industry's enterprise presents "the few 
big enterprises, the massive Small business" characteristic, The enterprise assets scale is generally small, the middle and small scale Cultural enterprise occupies the overwhelming majority, only a few enterprise has competition. At the same time, considered the New-model Culture Industry has high risk financing, lacks enough management information and "Macmillan gap", the New-model Culture Industry development direct finance. The direct finance has irreplaceable screening and supervising mechanism. That is standard mechanism, the fund raising mechanism, the society supervising mechanism and the entrepreneur cultivation and the standard mechanism.

The direct finance may also promote the small and medium-sized enterprise perfect company to govern, realizes the standard development The New-model Culture Industry Enterprise in our country is development rapidly, but substandard management behavior is also common, through the direct finance, we can increases the restraint of the Supervisory department, the market and the media, and it will helpful in this type enterprise management structure improvement.

\subsection{The fuzzy synthetic rating model of the New-model Culture Industry's enterprise value growth potential}

According to the New-model Culture Industry enterprise's investment present situation, in order to seek for a better investment, a rating enterprise value growth potential's fuzzy synthetic evaluation system is essential. Through appraisal enterprise value drivers factor, and connect financial norm performance and non-financial norm together, provides the basis for enterprise's direct finance.

\subsubsection{Determination synthetic evaluation's factor set}

\section{Insert Table 1 here}

3.2.2 Establish appraisal set, and carry on the single factor appraisal

Appraisal set is the expert who made the evaluation level to the appraisal object. This case has 20 experts to carry on the appraisal, is divided five ranks, respectively is "A, B, C, D, and E." Appraisal set $\mathrm{V}=\left(\mathrm{V}_{1}, \mathrm{~V}_{2}, \mathrm{~V}_{3}, \mathrm{~V}_{4}, \mathrm{~V}_{5}\right)$

\section{Insert Table 2 here}

From the Table 2 we get RUF Moment $\mathrm{R}_{11}$ of $\mathrm{U}_{11}$.

\subsubsection{Identified the weights of the factors}

This case determination to the factors weights by the Delphi method. $U_{i}$ as $U$ 's weight is $W=\left(W_{1}, W_{2}, W_{3}\right)$; $U_{i j}$ as $U_{i}$ 's weight is $\mathrm{W}_{1}=\left(\mathrm{W}_{11}, \mathrm{~W}_{12}\right) ; \mathrm{W}_{2}=\left(\mathrm{W}_{21}, \mathrm{~W}_{22}, \mathrm{~W}_{23}, \mathrm{~W}_{24}\right)$; and so on.

$$
\begin{aligned}
& \mathrm{W}=(0.35,0.4,0.25) \\
& \mathrm{W}_{1}=(0.4,0.2) \\
& \mathrm{W}_{2}=(0.35,0.25,0.2,0.2) \\
& \mathrm{W}_{3}=(0.35,0.3,0.2,0.15) \\
& \ldots \ldots \\
& \mathrm{W}_{33}=(0.3,0.25,0.25,0.2)
\end{aligned}
$$

3.2.4 Calculates the fuzzy matrix, obtains the measure results

$$
\mathrm{B}=\mathrm{W} \circ \mathrm{R}
$$

B is fuzzy synthetic evaluation of the case. "O" is a broad synthesis of computing. We used one of its model M (·, $\odot)$. Because this model take into account the impact of comprehensive evaluation of various factors, and to retain the single-factor evaluation of all of the information. Through to the third factors carried on the first-level synthesis judgment, and carried on the second-level synthesis judgment and the third-level synthesis judgment in turn in the first-level judgment's foundation. Finally we get the result.

$\mathrm{B}=\mathrm{W} \cdot \mathrm{R}=(0.2865625,0.32596875,0.22025,0.03880625)$

According to the biggest degree of membership principle, the enterprise value growth potential belongs to "B".

\section{Acknowledgement}

This paper is the short-term research results for Tianjin Social Science Fund Projects, and the Cultural Projects number is $D 0603-028$.

\section{References}

Chen, Feng. (2008). The new culture industry's challenge, opportunity and situation which faced[EB/OL].http://www.chinagate.com.cn.

Gu, Jiang. (2007). Culture industrial economics. Jiangsu Nanjing: Nanjing University Publishing house.

Jiang, Xiaojie. (2004). Research of Chinese direct finance innovation. Northeast Finance and economics University. 
Table 1. Fuzzy synthetic evaluation's factors sets norm constitution

\begin{tabular}{|c|c|c|c|}
\hline aim & $\begin{array}{l}\text { The first } \\
\text { factors (the } \\
\text { third-level } \\
\text { judgment) }\end{array}$ & $\begin{array}{l}\text { the second factors } \\
\text { (the second } \\
\text { judgment) }\end{array}$ & The third factors (the first-class judgment \\
\hline \multirow{33}{*}{$\begin{array}{c}\text { Ente } \\
\text { rpris } \\
\text { e } \\
\text { valu } \\
\text { e } \\
\text { grow } \\
\text { th } \\
\text { pote } \\
\text { ntial } \\
\text { (U) }\end{array}$} & \multirow{5}{*}{$\begin{array}{c}\text { Shareholder } \\
\text { satisfaction( } \\
\left.\mathrm{U}_{1}\right)\end{array}$} & \multirow{2}{*}{$\begin{array}{l}\text { Shareholders } \\
\text { ROI }\left(\mathrm{U}_{11}\right)\end{array}$} & Economic Value Added $\left(\mathrm{U}_{111}\right)$ \\
\hline & & & Rights of return $\left(\mathrm{U}_{112}\right)$ \\
\hline & & \multirow{3}{*}{$\begin{array}{l}\text { Concentration of } \\
\text { shares }\left(\mathrm{U}_{12}\right)\end{array}$} & the three major shareholders stake $\left(\mathrm{U}_{121}\right)$ \\
\hline & & & the five major shareholders stake $\left(\mathrm{U}_{122}\right)$ \\
\hline & & & the ten major shareholders stake $\left(\mathrm{U}_{123}\right)$ \\
\hline & \multirow{16}{*}{$\begin{array}{c}\text { Employee } \\
\text { Satisfaction( } \\
\left.\mathrm{U}_{2}\right)\end{array}$} & \multirow{3}{*}{ Staff salaries $\left(\mathrm{U}_{21}\right)$} & The average annual income of employees $\left(\mathrm{U}_{211}\right)$ \\
\hline & & & Staff revenue growth $\left(\mathrm{U}_{212}\right)$ \\
\hline & & & Operators salaries $\left(\mathrm{U}_{213}\right)$ \\
\hline & & \multirow{3}{*}{$\begin{array}{c}\text { Employee } \\
\text { participation in } \\
\text { decision-making } \\
\left(\mathrm{U}_{22}\right)\end{array}$} & The staff recommended rate $\left(\mathrm{U}_{221}\right)$ \\
\hline & & & $\begin{array}{l}\text { The per capita number of recommendations to } \\
\text { rationalize }\left(\mathrm{U}_{222}\right)\end{array}$ \\
\hline & & & suggestion accepted returns rate $\left(\mathrm{U}_{223}\right)$ \\
\hline & & \multirow{6}{*}{$\begin{array}{l}\text { Overall quality of } \\
\text { employees }\left(\mathrm{U}_{23}\right)\end{array}$} & Operators of the posts Work Experience $\left(\mathrm{U}_{231}\right)$ \\
\hline & & & Operator's health and age $\left(\mathrm{U}_{232}\right)$ \\
\hline & & & Operator stake $\left(\mathrm{U}_{233}\right)$ \\
\hline & & & Staff qualifications and the proportion $\left(\mathrm{U}_{234}\right)$ \\
\hline & & & The average age of $\operatorname{staff}\left(\mathrm{U}_{235}\right)$ \\
\hline & & & Proportion of professional and technical personnel( $\left.\mathrm{U}_{236}\right)$ \\
\hline & & \multirow{4}{*}{$\begin{array}{c}\text { Staff skills } \\
\text { development }\left(\mathrm{U}_{24}\right)\end{array}$} & The cost of education and training $\left(\mathrm{U}_{241}\right)$ \\
\hline & & & Professional training days $\left(\mathrm{U}_{242}\right)$ \\
\hline & & & Management staff to receive training days $\left(\mathrm{U}_{243}\right)$ \\
\hline & & & Per capita training costs $\left(\mathrm{U}_{244}\right)$ \\
\hline & \multirow{12}{*}{$\begin{array}{c}\text { Customer } \\
\text { Satisfaction( } \\
\left.\mathrm{U}_{3}\right)\end{array}$} & \multirow{4}{*}{$\begin{array}{l}\text { Product / service } \\
\text { quality }\left(\mathrm{U}_{31}\right)\end{array}$} & Products pass rate $\left(\mathrm{U}_{311}\right)$ \\
\hline & & & Product percentage of products sent back for repair $\left(\mathrm{U}_{312}\right)$ \\
\hline & & & Product returning goods rate $\left(\mathrm{U}_{313}\right)$ \\
\hline & & & Production cycle $\left(\mathrm{U}_{314}\right)$ \\
\hline & & \multirow{4}{*}{$\begin{array}{c}\text { Product } \\
\text { Innovation }\left(\mathrm{U}_{32}\right)\end{array}$} & New product development success rates $\left(\mathrm{U}_{321}\right)$ \\
\hline & & & $\mathrm{R} \& \mathrm{D} \operatorname{costs}\left(\mathrm{U}_{322}\right)$ \\
\hline & & & New product development cycle $\left(\mathrm{U}_{323}\right)$ \\
\hline & & & Brand awareness $\left(\mathrm{U}_{324}\right)$ \\
\hline & & \multirow{4}{*}{$\begin{array}{l}\text { After-sales } \\
\text { service }\left(\mathrm{U}_{33}\right)\end{array}$} & On time delivery rate $\left(\mathrm{U}_{331}\right)$ \\
\hline & & & Successful resolution of complaints rate $\left(\mathrm{U}_{332}\right)$ \\
\hline & & & response the complaints rate $\left(\mathrm{U}_{333}\right)$ \\
\hline & & & On-site service speed $\left(\mathrm{U}_{334}\right)$ \\
\hline
\end{tabular}


Table 2. Measure results table

\begin{tabular}{|c|c|c|c|c|c|c|}
\hline \multirow{2}{*}{$\begin{array}{c}\text { The } \\
\text { secon } \\
d \\
\text { factor } \\
\text { s }\end{array}$} & $\begin{array}{l}\text { The } \\
\text { third } \\
\text { facto }\end{array}$ & \multicolumn{5}{|c|}{ Opinion rating and ratio } \\
\hline & & $\mathrm{V}_{1}$ & $\mathrm{~V}_{2}$ & $\mathrm{~V}_{3}$ & $\mathrm{~V}_{4}$ & $\mathrm{~V}_{5}$ \\
\hline \multirow{2}{*}{$\mathrm{U}_{11}$} & $\mathrm{U}_{111}$ & 0.5 & 0.25 & 0.1 & 0.05 & 0.1 \\
\hline & $\mathrm{U}_{112}$ & 0.6 & 0.15 & 0.2 & 0.05 & 0 \\
\hline \multirow{3}{*}{$\mathrm{U}_{12}$} & $\mathrm{U}_{121}$ & 0.6 & 0.2 & 0.1 & 0.05 & 0.05 \\
\hline & $\mathrm{U}_{122}$ & 0.5 & 0.15 & 0.2 & 0.1 & 0.05 \\
\hline & $\mathrm{U}_{123}$ & 0.7 & 0.1 & 0.05 & 0.1 & 0.05 \\
\hline \multirow{3}{*}{$\mathrm{U}_{21}$} & $\mathrm{U}_{211}$ & 0.3 & 0.3 & 0.3 & 0.1 & 0 \\
\hline & $\mathrm{U}_{212}$ & 0.2 & 0.4 & 0.3 & 0.1 & 0 \\
\hline & $\mathrm{U}_{213}$ & 0.3 & 0.5 & 0.2 & 0 & 0 \\
\hline \multirow{3}{*}{$\mathrm{U}_{22}$} & $\mathrm{U}_{221}$ & 0 & 0.2 & 0.3 & 0.4 & 0.1 \\
\hline & $\mathrm{U}_{222}$ & 0 & 0.3 & 0.2 & 0.3 & 0.2 \\
\hline & $\mathrm{U}_{223}$ & 0 & 0.3 & 0.15 & 0.5 & 0.05 \\
\hline \multirow{6}{*}{$\mathrm{U}_{23}$} & $\mathrm{U}_{231}$ & 0.4 & 0.2 & 0.3 & 0.1 & 0 \\
\hline & $\mathrm{U}_{232}$ & 0.35 & 0.35 & 0.25 & 0.05 & 0 \\
\hline & $\mathrm{U}_{233}$ & 0.2 & 0.3 & 0.4 & 0.1 & 0 \\
\hline & $\mathrm{U}_{234}$ & 0.4 & 0.5 & 0.1 & 0 & 0 \\
\hline & $\mathrm{U}_{235}$ & 0.4 & 0.3 & 0.2 & 0.1 & 0 \\
\hline & $\mathrm{U}_{236}$ & 0.3 & 0.4 & 0.25 & 0.05 & 0 \\
\hline \multirow{4}{*}{$\mathrm{U}_{24}$} & $\mathrm{U}_{241}$ & 0 & 0.4 & 0.5 & 0.1 & 0 \\
\hline & $\mathrm{U}_{242}$ & 0 & 0.35 & 0.4 & 2 & 0.05 \\
\hline & $\mathrm{U}_{243}$ & 0 & 0.4 & 0.4 & 0.2 & 0 \\
\hline & $\mathrm{U}_{244}$ & 0 & 0.2 & 0.5 & 0.2 & 0.1 \\
\hline \multirow{4}{*}{$\mathrm{U}_{31}$} & $\mathrm{U}_{311}$ & 0.5 & 0.4 & 0.1 & 0 & 0 \\
\hline & $\mathrm{U}_{312}$ & 0.6 & 0.3 & 0.1 & 0 & 0 \\
\hline & $\mathrm{U}_{313}$ & 0.4 & 0.5 & 0.05 & 0.05 & 0 \\
\hline & $\mathrm{U}_{314}$ & 0.5 & 0.35 & 0.15 & 0 & 0 \\
\hline \multirow{4}{*}{$\mathrm{U}_{32}$} & $\mathrm{U}_{321}$ & 0 & 0.3 & 0.6 & 0.1 & 0 \\
\hline & $\mathrm{U}_{322}$ & 0 & 0.3 & 0.5 & 0.05 & 0.05 \\
\hline & $\mathrm{U}_{323}$ & 0 & 0.2 & 0.5 & 0.2 & 0.1 \\
\hline & $\mathrm{U}_{324}$ & 0 & 0.4 & 0.4 & 0.2 & 0 \\
\hline \multirow{4}{*}{$\mathrm{U}_{33}$} & $\mathrm{U}_{331}$ & 0.2 & 0.7 & 0.1 & 0 & 0 \\
\hline & $\mathrm{U}_{332}$ & 0.2 & 0.6 & 0.1 & 0.1 & 0 \\
\hline & $\mathrm{U}_{333}$ & 0 & 0.5 & 0.4 & 0.1 & 0 \\
\hline & $\mathrm{U}_{334}$ & 0.2 & 0.4 & 0.3 & 0.1 & 0 \\
\hline
\end{tabular}

